The problem of the two synthetic hormones still allowed as additives, trenbolone and zeranol, is that the data are considered insufficient. Partly in answer to requests by the industry the Commission agreed to further research and reconvened the Lamming group. Its failure to report last autumn is seen by BEUC as an indication that the European Commission is bowing yet again to pressure from member states and interested parties.

European Commission officials deny this but admit that political pressure is so strong, on both sides, that scientific views may not really be taken into consideration.

The report may not now appear before the end of 1985, but, according to Professor Lamming, the reasons behind the delay are technical. Consumer concern, he says, has generated much new research into the two compounds. Analysing all the data takes time.

The evaluation of the latest data has also raised questions about the reliability and relevance of test methods. The immediate objective is to tell whether there is a threshold dose of hormones below which no effects appear, but this is more than usually complicated by doubts about the relevance of tests with laboratory species to the potential hazards of such compounds in humans.

Anna Lubinska

\section{Danube dam stopped}

Work on the controversial GabcikovoNagymaros hydroelectric project (see Nature 311,$293 ; 1984$ and 313 171; 1985) has now been halted, Mr Matyas Szuros, secretary of the Central Committee of the Hungarian Socialist Workers' Party revealed last week. This means, in effect, that the Czechoslovak government has agreed to a moratorium on the almost completed diversion and dam at Gabcikovo. Work on the Hungarian dam at Nagymaros was stopped in 1981 for lack of funds and under pressure from Hungarian ecologists fearing irrevocable damage to the water-table of north-west Hungary, destruction of river-life and the drowning of the scenic "Danube Bend", Budapest's chief resort area.

Interviewed on Budapest radio, Szuros explained that when the agreement for the scheme was first signed in 1977 , the effect on the environment could not be calculated. The two governments, Szuros said, had modified the original agreement "on the basis of mutual agreement" in 1983. This would imply that the moratorium had been agreed before the environmentalists' petition against the dam and the clamp-down on public discussion of the project at the beginning of 1984 .

According to Szuros, there is now until the middle of 1985 to "analyse in a comprehensive way, carry out scientific research and assess the potential further effects on the environment" of completion of the project.

Vera Rich

Radioactive waste

\title{
Disunited states urged to act
}

Washington

STATES could soon face serious problems disposing of low-level radioactive waste, unless efforts now under way in the US Congress succeed in breaking the political stalemate which, for the past four years, has prevented the development of new disposal sites.

The radioactive waste materials concerned consist mostly of discarded laboratory equipment and clothing. Arrangements for the disposal of highly active wastes, such as arise in fuel reprocessing, are covered by separate legislation.

A law passed in 1980 gave states until 1 January 1986 to form themselves into regional compacts responsible for their own waste disposal, after which date the three existing disposal sites would be able to exclude waste from other regions. States lacking their own disposal sites have, however, blocked the required congressional approval allowing them to do so; in retaliation, the three states with sites have threatened to close them down completely if they are required to take out-of-region waste after next year. It is still unclear how a short-term crisis will be avoided.

Some 2.7 million cubic feet of low-level waste are produced each year in the United States, half of it by electrical utilities and half by hospitals and research institutes. The need to develop new sites will become urgent as the rate of waste production increases; roughly 40 per cent more waste will be produced each year by 2007 . Most states have now reached provisional compact agreements under the low-level radioactive waste policy act, but as choosing and developing a suitable site can take five years, some urgent interim arrangements are necessary. Congress is thought unlikely to grant the necessary approval for formation of regional compacts until a solution to the immediate problem is found.

The latest attempt at a political solution is a bill introduced in the House of Representatives by Congressman Morris Udall (Democrat, Arizona). Udall's bill, which arose out of extensive consultations with state governments, would require states without disposal sites to submit within one year plans for developing sites; the states with operating sites would be obliged to continue taking limited quantities of outof-region waste until 1993. Udall's bill, which is in the form of an amendment to the 1980 act, would also provide a standard form of agreement for compacts. But even in the bill does prove politically acceptable, in its present form it would provide only a partial solution to the growing waste problem.

There is general agreement among states that the two major sites now in operation (at Barnwell, South Carolina, and Hanford, Washington) should take less waste in future than they do now. Under Udall's proposal they would have to take each year only 60 per cent of the amount of waste they received from outside their compacts in 1983; a third, much smaller, site in Nevada would have to take only 150,000 cubic feet of out-of-region waste. Udall makes no provision for the remaining 40 per cent, and some states are making plans for drastic action.

One widely discussed option is that power companies might be required to store their low-level wastes at power stations for five years, after which time it is hoped new sites will be nearing completion. The proposal is, not surprisingly, being resisted strongly by the utilities; the American Nuclear Energy Council, a lobbying group, is pushing for "good faith agreements" between states to ensure continued access to the existing sites. But supporters of the five-year storage idea point out that it would reduce waste production to under 60 per cent of the 1983 level and so perhaps solve the crisis.

Although not included in Udall's bill, the five-year storage plan is likely to be discussed at forthcoming meetings of state representatives where the waste issue will be tackled. There is, however, general recognition that any solution is likely to be fraught with legal complications, because agreements between states come close to the dangerous ground of balance of power between states and the federal government.

Two provisional regional compacts have already been submitted for approval in the 99th Congress and three more are expected to follow shortly. The outlines, at least, of compact agreements can be discerned for most of the country, though with negotiations at different stages. Negotiations centre on procedures for deciding where in each compact a new disposal site would be built; some compact agreements specify, for example, that all member states producing more than a certain percentage of total waste must have a site in their own territory.

The major political log-jam is in the north-east of the country, where Massachusetts and New York, both major producers, have refused to form compacts with New England states. Massachusetts, under a state law known as chapter 503, cannot join a compact or approve a site decision until a public referendum is held which cannot be until mid-1986, after the legal deadline for formation of compacts. Both New York and Massachusetts may be forced to consider temporary storage facilities and to impose draconian wastereduction measures that would go beyond the voluntary efforts made so far. As for what will happen in the longer term, the answer is, in the words of one analyst following the issue, "anybody's guess".

Tim Beardsley 